\title{
Real exchange rate and manufacturing growth in Latin America
}

\author{
Paulo Henrique Vaz $\cdot$ Werner Baer
}

Received: 10 May 2013/ Accepted: 4 September 2013/Published online: 7 February 2014

(C) The Author(s) 2014. This article is published with open access at Springerlink.com

\begin{abstract}
The manufacturing sectors in Latin America have been more affected by the currency over/undervaluation than their counterpart in industrialized economies. From a panel data set covering 39 countries and 22 manufacturing sectors (2-digit) within 1995-2008, we formally test the hypothesis that there exists a Latin American effect and then investigate the possible reasons for this distinguished pattern. The use of a disaggregated data is an important feature of our empirical strategy: the undervaluation index (main covariate) is less likely to be determined by the growth rate of a specific manufacturing sector, partially addressing the specification problem that plagues standard cross-country regressions. We then explore the within sector-country variation to study the relationship between currency over/undervaluation and manufacturing sectors growth. We find that the import content of exports might be an important driver of this result at a sectoral level. At a macro-level, the openness and the income per capita of a country are important factors.
\end{abstract}

Keywords Real currency appreciation · De-industrialization · Manufacturing growth · Latin America

JEL Classification $\mathrm{O} 23 \cdot \mathrm{O} 24 \cdot \mathrm{O} 25$

\footnotetext{
P. H. Vaz

University of Illinois at Urbana-Champaign, 214 David Kinley Hall, 1407 W. Gregory Dr., Urbana, IL 61801, USA

e-mail: pereira6@illinois.com

W. Baer $(\bowtie)$

University of Illinois at Urbana-Champaign, 218 David Kinley Hall, 1407 W. Gregory Dr., Urbana, IL 61801, USA

e-mail: wbaer@illinois.edu
} 


\section{Introduction}

After World War II most large Latin American countries chose import substitution industrialization (ISI) as their main economic development strategy. Their policymakers accepted the Prebisch/ECLA analysis, which took a pessimistic view of the future world demand for their traditional primary exports and recommended ISI as the solution to their quest for economic growth and development. They closed their economies (using various protective measures), encouraged foreign direct investments through various incentive schemes, pursued inflationary public investment policies to allocate resources in priority sectors, and kept their exchange rates fixed. These measures gradually resulted in an overvalued exchange rate, causing severe balance of payments difficulties, which, after a period of speculation against the currency, usually led to devaluation.

By the first decade of the twenty-first century the situation of these countries had changed substantially. In the 1990s they had adopted neoliberal policies, which consisted of the opening of their economies (drastically reducing the ISI protective walls), massive privatization of state enterprises, effective stabilization policies which ended the hyperinflations of the 1970s and 1980s, and the opening of many sectors from which foreign investors had been excluded. Most countries central banks adopted an inflation targeting policy, whose principal instrument to control prices, was a high real rate of interest which was considerably higher than the rate of interest which prevailed in many industrial countries. All this was taking place while China and other Asian economies were undergoing an industrial boom, which greatly increased the demand for minerals and food. The resulting higher commodity prices dramatically raised export earnings of Latin American countries.

Thus, by the second half of the first decade of the twenty-first century, these Latin American countries were in a paradoxical situation. Their currencies were appreciating relative to the US dollar and the Euro as a result of both large capital inflows (due to the high relative interest rates) and trade surpluses due the high prices of commodities, which they exported to Asia. Appreciation, however, was said to be threatening the industrial sectors which had been built up since the midtwentieth century, by both making Latin American manufactured goods less competitive internationally and by increasing imports of foreign manufactured goods which were getting cheaper. Some economists have been calling this a situation which threatened to de-industrialize Latin America.

Table 1 provides some economic indicators of major Latin American economies during the period 2001-2009. As can be noted, they all experienced currency appreciation, increased of net foreign direct investment (FDI) as well as an increase (in absolute value) of net resource transfer. Structurally, most had a high interest rate and positive net FDI during the period.

Surprisingly, it would seem that both situations-the ISI experience and the neoliberal experience-resulted in an overvalued exchange rate. In the former, the combination of protection, fixed exchange rate and inflation led to overvaluation; this usually led to a balance of payments crisis, speculation against the currency, and, finally, devaluation. In the case of the neo-liberal economies of the first decade of the twenty-first century, a combination of high interest rates, an open economy 
and capital inflows resulted in appreciating (and overvaluing) the currency. As far as exports of commodities are concerned, in the ISI period their prices were weakened due to the low growth of demand (see the Prebisch analysis), while during the neoliberal period, with the strong growth of Asian demand, their prices were rising as exports grew. As the impact of the ISI has been widely studied, we shall focus on the neo-liberal experience. ${ }^{1}$

\subsection{The Rodrik vision}

It is interesting to contrast the recent Latin American experience in the first decade of the twenty-first century with the vision of Dani Rodrik, who in a recent study came to the conclusion that "...Avoiding significant overvaluation of the currency is one of the most robust imperatives that can be gleaned from the diverse experience with economic growth around the world, and one that appears to be strongly supported by cross-country statistical evidence." (Rodrik 2008, p. 365). And further on he states that "...Just as overvaluation hurts growth, so undervaluation facilitates it.” (Rodrink 2008, p. 366). However, he notes that “...this relationship holds only for developing countries; it disappears when the same is restricted to richer countries, and it gets stronger the poorer the country." (p. 366).

For South America, with primary commodity booms and high interest rates attracting huge inflows of speculative capital, appreciation may have made most of its manufactured products less internationally competitive. In some cases cheaper manufactured imports may have been partially controlled through the countervailing effect of stimulated demand for domestic manufactured goods through temporary sales tax cuts (as happened in Brazil in 2011-2012, or in some cases through the lower costs of imported intermediate goods). The final effect of such appreciation in the industrial sector remains therefore inconclusive.

The aim of this paper is to investigate the effect of currency over/undervaluation on manufacturing production in Latin America in the 1995-2008 period through cross-country cross-sector regressions. We shall follow the same structure as in Rodrik (2008). However, our approach is different, as we are dealing directly with a disaggregated industrial sector in order to reveal the Latin American effect. The hypothesis that Latin America has been more strongly affected by currency overvaluation is investigated by controlling for country and sector characteristics and fixed effects, which will allow us to shed some light on the reasons behind the stronger Latin American effect.

\section{Empirical evidence}

There is some consensus that the real exchange rate matters for economic growth. According to Rodrik (2008), undervaluation of the currency stimulates economic growth and is more likely to be effective for developing countries. Rodrik's

\footnotetext{
1 See Baer (1964, 1972, 1984 and 2014) and Little et al. (1970).
} 
argument is based on a panel data set in which growth is explained among other variables by an index of undervaluation.

The index of undervaluation, the main covariate in the model, is a measure of domestic price level adjusted for the Balassa-Samuelson effect. ${ }^{2}$ The index is computed in three steps: first, by calculating the real exchange rate (RER) through the purchasing power parity conversion factor (PPP); second, by regressing the RER on per capita GDP we obtain the estimated Balassa-Samuelson effect; finally, the undervaluation index is obtained by the ratio of the real exchange rate to the predicted value from the second step, i.e., the Balassa-Samuelson-adjusted rate. Whenever the undervaluation index exceeds one, the currency is considered undervalued. Fortunately, as an index it allows comparisons across countries and over time.

Given this measure of under or overvaluation, Rodrik's goal was to find evidence of a positive relationship between growth and undervaluation. From a sample of 188 countries and 11 five-year periods from 1950 to 2004, the baseline specification form is:

$$
\begin{aligned}
\text { growth }_{\mathrm{it}}= & \alpha+\beta \ln \mathrm{RGDPCH}_{i, t-1}+\delta_{1} \ln \mathrm{UNDERVAL}_{\mathrm{it}} \\
& +\delta_{2} \ln \mathrm{RGDPCH}_{\mathrm{i}, \mathrm{t}-1} \times \ln \mathrm{UNDERVAL}_{\mathrm{i}, \mathrm{t}}+f_{i}+f_{t}+u_{\mathrm{it}}
\end{aligned}
$$

where the dependent variable, annual growth in GDP per capita, is explained by initial real income per capita, $\mathrm{RGDPCH}_{I, t-1}$, the undervaluation index, the interaction between them and the country and time dummies.

The result suggests that currency undervaluation affects growth rates positively except in the case of "anomalous" Latin American economies. The effect depends on the initial level of income per capita and is stronger for the sample of developing countries. Based on this evidence, Rodrik named the Mexican case, where the undervaluation is negatively related to growth, as the "anomalous Latin American case". Nevertheless, as shown in Fig. 1, by verifying in an analogous manner the situation of other major Latin American economies (such as Argentina, Brazil, Chile, Colombia and Peru) one could conclude that the Mexican case is not an exception within Latin America context. One could claim that the primary commodity booms are confounding the effect of exchange rate variations since it might be causing both appreciation and GDP growth. We therefore propose a different empirical strategy in order to verify to what extent the industrial sectors in Latin America have been negatively or positively affected by the recent currency appreciation episodes: a cross-country cross-sector analysis within 1995-2008.

Regarding sectorial effects, one can highlight four ways in which the real exchange rate appreciation could affect manufacturing sectors performance. First, the real appreciation of the currency makes manufactured goods more expensive internationally, thus reducing their international competitiveness. Second, imported manufactured goods become cheaper, challenging the domestic industrial sector. On the other hand, appreciation could also benefit the manufacturing sector. An

\footnotetext{
2 The "Balassa-Samuelson" effect was formulated by Balassa (1964) and Samuelson (1964). It describes the distortion in purchasing power parity (PPP) resulting from the international differences in relative productivity between the tradable goods sector and the non-tradable goods sector.
} 

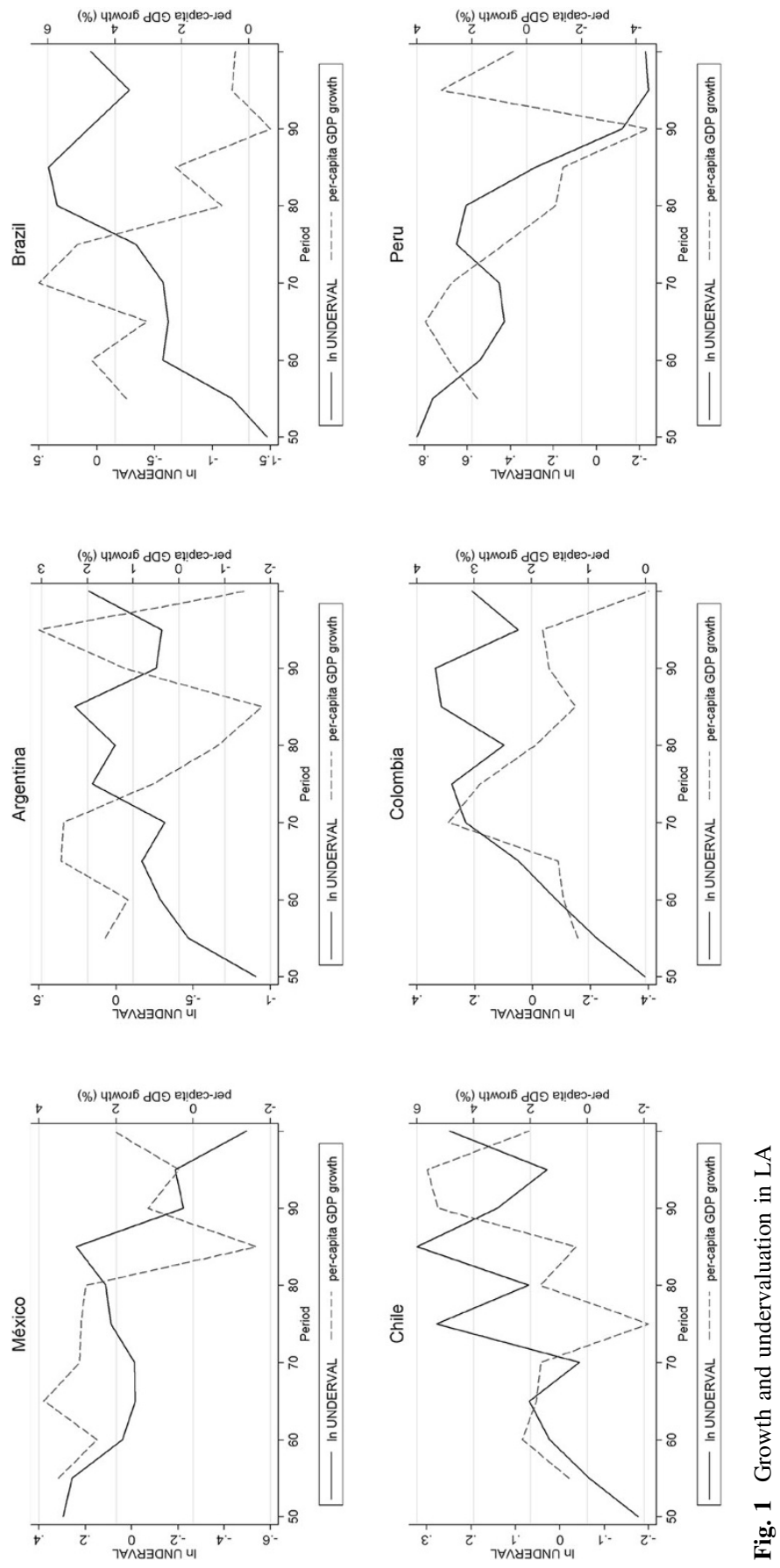
overvalued currency makes imported intermediate goods cheaper, reducing production cost, which may affect investment decisions, as well as the price competitiveness of the industrial sector in the domestic and international market. Furthermore, if such appreciation is due to an increasing demand of primary commodities, the income effect may raise the domestic consumption of manufactured goods. ${ }^{3}$ It is thus necessary to carefully check which one of the four effects has prevailed in Latin America in the last decades. An industrial sector-level analysis turns out to be a reasonable way to investigate it, conditional on the heterogeneous characteristics of each country and sector.

\section{The data and econometric model}

\subsection{Identification strategy}

Recent empirical studies have tried to identify the currency under/overvaluation effects on economic growth by running cross-country regressions from panel sets with the country output growth as the explained variable and the exchange rate or an undervaluation index as one of the covariates in the model. ${ }^{4}$ The authors acknowledge some known identification problems, such as the multicausality between growth and the exchange rate as well as the possibility of a third factor affecting both growth and the exchange rate. Although applying GMM techniques have been the common treatment to these problems, a disaggregated sectorial analysis could identify its effect through a more direct and cleaner manner.

The use of a longitudinal dataset representing the industrial sectors for different countries and years allows a better identification. ${ }^{5}$ First, as highlighted by Eichengreen (2008), it is most unlikely that the output of a specific industrial sector will be determining the exchange rate. Figure 2 depicts the distribution of output share of each sector relative to the countries total manufacturing production; on average each sector studied here represents a small share of the country's total manufacturing production, mostly concentrated below $10 \%$. Second, considering the heterogeneity across sectors, the model allows controlling for sectorial characteristics. As mentioned before, we should expect that some sectorial features would determine the heterogeneous effect of currency under or overvaluation on their output growth. Third, one could argue that by checking the effects on the

\footnotetext{
${ }^{3}$ According to Shafaeddin (2005), during the 1990s the import intensity of the industrial sector of Chile, Colombia, Peru and Brazil increased. This can be considered evidence of the positive effects which could arise from currency appreciation in these countries.

${ }^{4}$ See Rodrik (2008), Gala (2008) and Berg and Miao (2010).

${ }^{5}$ Berg and Miao (2010) and Rajan and Subramanian (2011) provide some support for this empirical strategy. In the first, the authors claim that "understanding the role of the real exchange rate for growth will probably require stepping away from the aggregate growth-regression framework employed here [cross-country regressions], in particular looking at more disaggregated evidence to see which channels are operating and perhaps to disentangle causality". In the latter, it was considered the key innovation of their paper, which "by absorbing country-specific variation in country indicators, and exploiting only the within-country across-industry variation, we go some way in addressing the specification problem that plague standard cross-country regressions".
} 


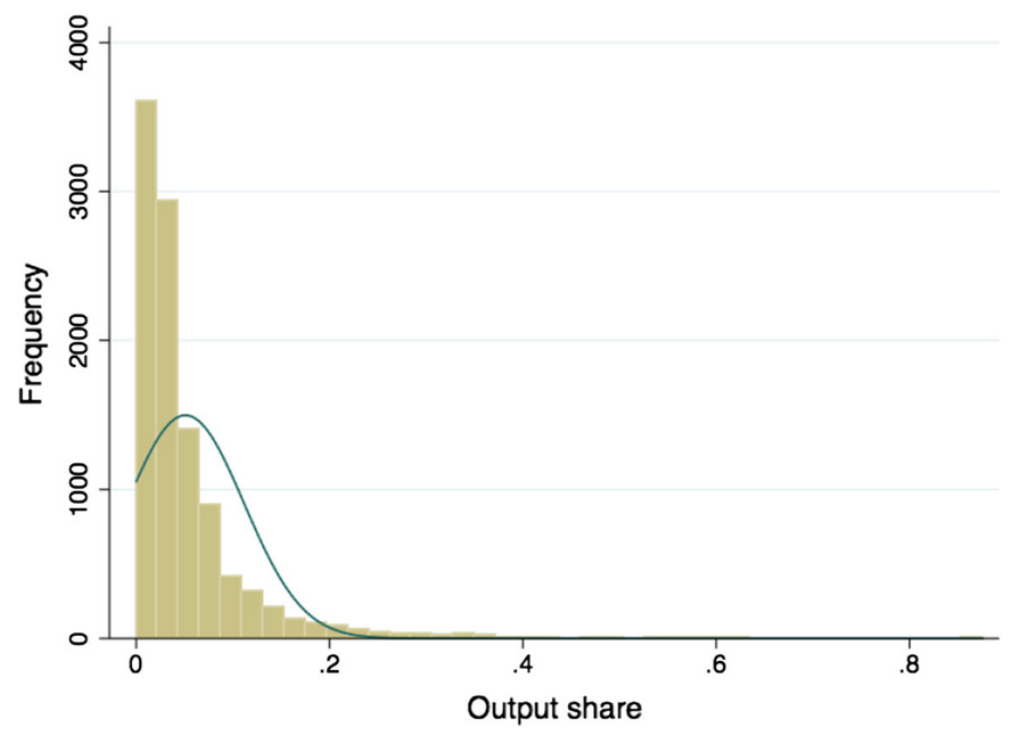

Fig. 2 Sector/country output share in the country

manufacturing sector directly, we substantially reduce the effects arising from the demand boom of primary commodities, which could be causing the spurious correlation previously described between national growth and currency appreciation in the case of Latin American economies.

\subsection{The data}

The models are estimated using unbalanced panel data covering 1995-2008 on a sample of 39 countries, including 8 Latin American and 31 Industrialized economies, built.$^{6}$ For each country the data cover 22 industrial sectors arranged at the 2-digit level of the International Standard Industrial Classification of all economic activities (ISIC) revision 3. The sectorial data are obtained by INDSTAT2, from United Nations Industrial Development Organization (UNIDO), which is the largest industrial statistics database of its kind. Rajan and Zingales (1998), Imbs and Wacziarg (2003) and Imbs (2007) are good reference on the use of UNIDO Industrial Statistics Database.

The data were based on three different sources. From UNIDO we obtained the dependent variable, which is the average annual growth rate of production in sector "s" in country "c". 7 The intermediate import ratio and the import content of exports

\footnotetext{
${ }^{6}$ LA countries: Argentina, Brazil, Chile, Colombia, Ecuador, Mexico, Peru, Uruguay. Other industrialized countries: Australia, Austria, Belgium, Bulgaria, Canada, Cyprus, Czech Republic, Denmark, Finland, France, Germany, Hungary, Ireland, Israel, Italy, Japan, Latvia, Lithuania, Luxembourg, Netherlands, Norway, Portugal, Republic of Korea, Romania, Singapore, Slovakia, Slovenia, South Africa, Spain, Sweden, United Kingdom and United States of America.

7 The real output growth is obtained through the production index multiplied by the output in current dollars at 2000 , the year by which the indexes are normalized to.
} 
were obtained from the OECD STAN input-output database, unfortunately they were not available on an yearly basis. We therefore used it as a time-invariant characteristic though it varies across countries and sectors. ${ }^{8}$ The Penn World Tables Aten et al. (2011) were used to get country controls: real GDP per capita (RGDPCH), openness (OpenK), real consumption and real investment share of GDP ( $\mathrm{Kc}$ and $\mathrm{Ki}$ ) as well as the real exchange rate, which was obtained through the purchasing power parity (PPP) conversion factor. The summary statistics, in Table 2, describe these variables for our sample.

As in Imbs (2007), the number of sectors in each country remains constant over time, but varies across countries. We kept sectors with at least 5 years of consecutive information. The remaining missing value in the data are assumed to be random since its pattern does not seem to be related to the specific situation of each sector or country. ${ }^{9}$

\subsection{The baseline model}

Our baseline model was constructed to capture the effect of currency under/ overvaluation on the output growth rates of several manufacturing sectors in different countries and then test the hypothesis of the Latin American effect. We model it similar to Rodrik (2008) to make it comparable to the current literature on the topic. Thus, the model we want to estimate is:

$$
\begin{aligned}
\operatorname{growth}_{c s, t}= & \alpha+\beta_{1} \ln y_{c s, t-1}+\beta_{2} \ln \mathrm{RGDPCH}_{\mathrm{c}, \mathrm{t}}+\delta_{1} \ln \mathrm{UNDERVAL}_{\mathrm{c}, \mathrm{t}} \\
& +\delta_{2} \mathrm{LA} \times \mathrm{UNDERVAL} \\
c, t & +f_{c s}+f_{t}+u_{c s, t}
\end{aligned}
$$

where, for country $c$, sector $s$ and year $t$ : the dependent variable, annual growth in production per capita, growth ${ }_{c s t}$, is explained by initial production per capita, $y_{\mathrm{cs}, t-1}$; the country's real income per capita, RGDPCH; the undervaluation index, Underval, and its interaction with a dummy for Latin American countries, LA; plus country-sector and time dummies, to account for time invariant country-sector unobserved features. The Haussman-Taylor test suggests the use of country-sector fixed effects rather than random effects. ${ }^{10}$

Table 3 shows the result of the baseline model estimation without country and sector controls. As in Rodrik (2008), the undervaluation index is positively correlated to sector output growth and statistically significant. If the currency is on average undervalued for an year, i.e., the index is greater than one, the growth rate of production is on average positively affected. As we should expect the sectorial

\footnotetext{
${ }^{8}$ In the case of Peru, Colombia, Ecuador and Uruguay, we used the mean for LA since the information was not available.

9 Regarding the possible relationship between country controls and missing observations, a logit regression of missing values for our dependent variable on country controls supports the absence of such a relationship. Variations of real GDP per capita does not change the likelihood of a country to conceal information about their manufacturing sector.

${ }^{10}$ We are implicitly assuming identical responses of annual growth of manufacturing sectors production to covariates such as Real GDP per capita (RGDPCH). We tested alternative formulations, which would allow for some heterogeneous effect within sectors or countries, however the estimated effect of undervaluation was not really sensitive to these modifications.
} 
output growth is highly correlated to the economy's overall performance, measured here by real income per capita. We highlight the result found when including the interaction with a dummy for LA countries: manufacturing sectors in LA have been more affected by the currency variations than their counterpart placed on industrialized countries. We then investigate some possible reasons for that result. Formally speaking, we go through the following steps: (1) add more country controls and check whether or not the result holds; (2) interact the undervaluation index with Country and sector characteristics to check what could be driving the result; (3) discuss the effect at a sectorial level and check whether the composition of manufacturing sectors is in favor of industrialized countries.

\subsection{Expanding the baseline model}

We decided to include more time-varying country controls in order to verify whether or not the Latin American Effect still holds. As shown in Table 4, even including some new country controls which are also related to exchange rate appreciation, such as the degree of openness, real private consumption and investment shares, the effect still holds.

Table 5 presents the result of the interaction of country and sector characteristics with the undervaluation index. At a macro-level, the initial income per capita of a country as well as its openness defines the effect of currency over or undervaluation. One may interpret it as: the richer the country, the lower the effect of real exchange rate variation on its manufacturing sectors. Moreover, the greater the openness the more exposed these sectors are to such variations. Since the average income per capita of Latin American countries in our samples is US\$8,295 against US\$26,318 for industrialized countries, it might be an important factor explaining the Latin American effect. The result resembles the Rodrik findings and could be used to explain the Latin American distinction.

Nonetheless, we should still investigate what characteristics of this early stage of development are driving the result. The openness could work the other way around. Latin American countries are known for their protectionist policies and the overall degree of openness is low when compared to industrialized countries in our sample, though it seems not strong enough to offset the other forces driving the Latin American effect.

At a micro level, the import content of exports seems to be an important ingredient. Intuitively, sectors presenting a higher ratio will be facing a reduction in cost whenever the national currency is overvalued and therefore alleviates the negative effect caused by the overvaluation. For the Latin American countries studied in this paper (see Table 6), the import content of manufacturing sectors is on average lower than in industrialized countries and the differences are particularly accentuated in some sectors.

\subsection{Breaking down the effect by sectors}

To exploit the sector-specific effect of the real exchange rate, we allow for the interaction between movements of our undervaluation index and a dummy variable 
for each sector. It permits different slopes among sectors, besides their fixed effect. Formally speaking, we want to estimate the following model:

$$
\begin{aligned}
\operatorname{growth}_{c s, t}= & \alpha+\beta_{1} \operatorname{lny}_{c s, t-1}+\beta_{2} \ln \mathrm{RGDPCH}_{c, t}+\beta_{3} X_{c t}+\delta_{1} \ln \mathrm{UNDERVAL}_{c t} \\
& +\delta_{2} \mathrm{LA} \times \mathrm{UNDERVAL}_{c t} \times D_{s}+f_{c s}+f_{t}+u_{c s, t}
\end{aligned}
$$

where:

$$
D_{s}=\sum_{i=1}^{21} D_{i}
$$

The estimation results are shown in Table 6. As we should expect, we do find some heterogeneity when we allow the Latin American effect to vary across manufacturing sectors. Though the causes of such heterogeneity demand a deeper study of each industry, accounting for their particularities, we will show the extent of such heterogeneity and try to make some connection with our previous findings.

Our result points to the import content of exports as an important factor on the sectorial level in explaining the heterogeneous effect of real exchange rate over or undervaluation on the performance of manufacturing sectors. By disaggregating the Latin American effect we can find some regularities related to that feature: (1) motor vehicles and other transport equipment (Isic 34 and 35) are the most sensitive to changes in the undervaluation index and both present low import ratio and import content of exports when compared to their counterpart in the sample of industrialized countries. (2) The sectors highly dependent on the imports of intermediate goods and with imports content of exports similar to the ones in industrialized economies presented a negative coefficient for the undervaluation index. ${ }^{11}$ In these cases, the currency overvaluation causes a nominal cost reduction which may offset the Latin American effect or even increase their growth rate of production rather than decrease it.

\section{Concluding remarks}

In this paper, we tested the hypothesis that manufacturing sectors in Latin American countries have been more affected by currency over or undervaluation than those placed in other industrialized countries in the 1995-2008 period. We controlled for sector and country characteristics to check for some possible explanations. The final goal was to make the result comparable to Rodrik (2008), in which the relationship between undervaluation and growth were drawn from cross-country analysis and, as a result, the effect on the manufacturing sector could not be inferred directly and the Latin American countries presented an anomalous pattern.

We conclude that manufacturing sectors in Latin America on average have been more affected by currency over or undervaluation. As found by Rodrik (2008), in this paper we ratify the importance of income per capita in determining its effect.

\footnotetext{
11 See Isic 30-32. The Isic 16- Tobacco products also present a negative effect that goes against the Latin American effect, but it presents a low Intermediate import ratio and low import content of exports. For this industry a investigation that goes beyond the scope of this paper is needed.
} 
Indeed, the stage of development could partially explain the difference found between sectors in Latin America and in industrialized economies. Nonetheless, we found that the degree of openness of a country as well as the sectorial import content of exports could be also important elements in explaining the distinct effect of real exchange rate movements on the production growth of industrial sectors. On average, manufacturing sectors in Latin America import fewer inputs and their exports have a high domestic content. Our result suggests that these sectorial features play an important role in explaining the sensitiveness of Latin American manufacturing sectors to currency over/undervaluation.

By disaggregating the Latin American effect among sectors, we provided a picture of which sectors have been most affected and used our previous findings to shed some light on the reasons for such heterogeneity. As a result, we found that sectors built during the ISI period such as, motor vehicles and other transport equipments, have been more affected than the average in Latin America, which might be explained by the low import content of their exports. The other sectors, such as IT, computing machinery and communication equipment, besides their small share, have presented the intermediate import ratio and the import content of export as high as in the manufacturing sectors of industrialized countries. The high dependence on imports, typical of these sectors, seems to affect the way they respond to currency appreciation/depreciation. In the case of the computing machinery, for instance, a currency overvaluation will likely increase the growth rate of production due to the reduced cost of imported inputs.

For policy purposes, our result seems to go along with Rodrik (2008)'s evaluation that an undervalued currency can be seen as a growth strategy. In the case of Latin American countries, the effect of such undervaluation could be even stronger; however, the quality of the growth could be questioned since it would be also more responsive to real exchange rate movements. These findings support the idea that the protectionist policies adopted in Latin America, aiming to help building the domestic industry by controlling the imports of some intermediate inputs, has a cost that we have been calling the Latin American effect.

Acknowledgments We would like to thank Daniel Dias, Heiwai Tang, Julimar Bechara and anonymous referees for many useful suggestions. The research of this article was partially financed by the Lemann Institute for Brazilian studies at the University of Illinois at Urbana-Champaign.

Open Access This article is distributed under the terms of the Creative Commons Attribution License which permits any use, distribution, and reproduction in any medium, provided the original author(s) and the source are credited.

\section{Appendix}

See appendix Tables 1, 2, 3, 4, 5 and 6. 


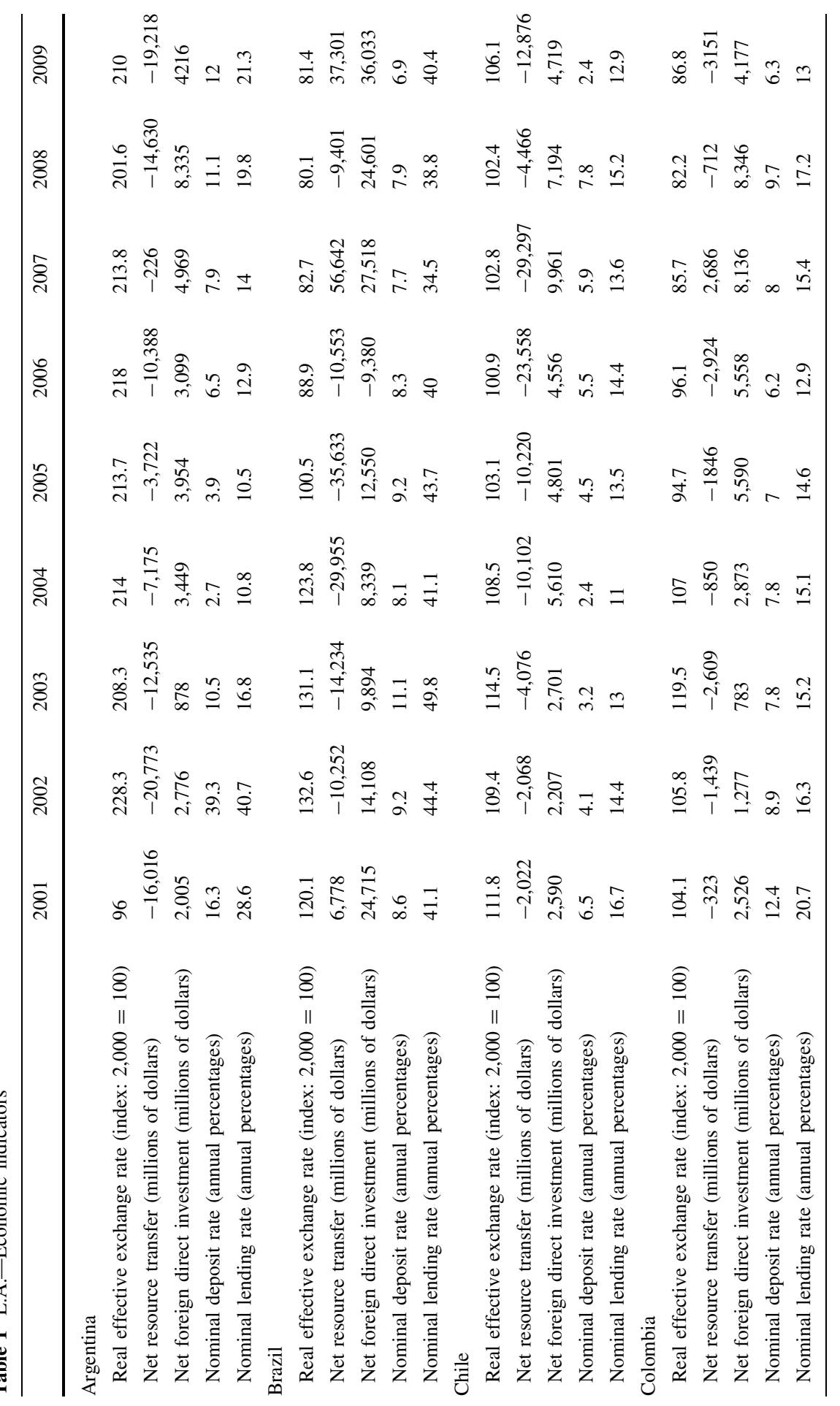




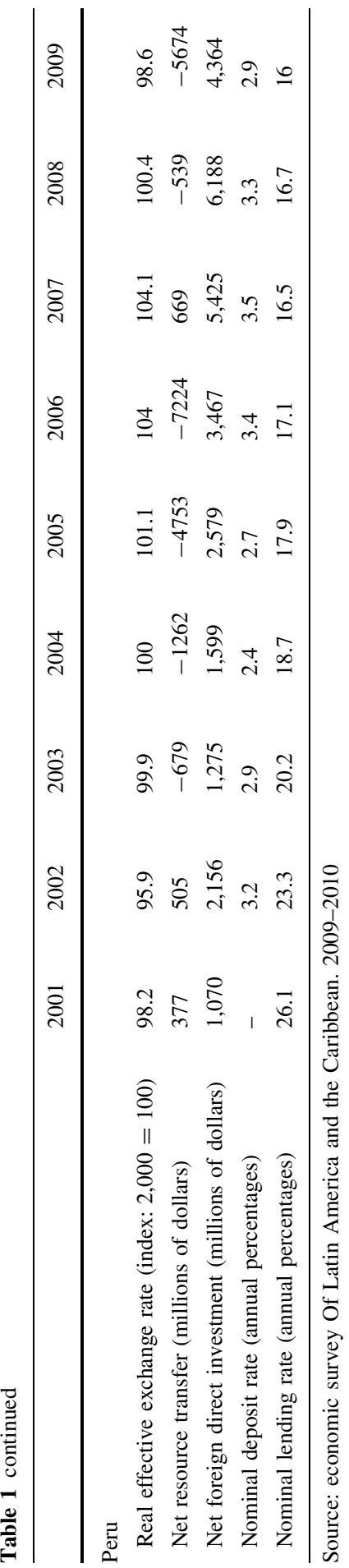


Table 2 Summary statistics

\begin{tabular}{lccccc}
\hline Variable & Obs & \multicolumn{1}{l}{ Mean } & Std. dev. & Min & Max \\
\hline Industrialized countries & & & & & \\
Growth rate of production per capita & 7,704 & -0.0006 & 0.2450 & -12.2270 & 0.8921 \\
Ln underval & 7,704 & 0.013 & 0.201 & -0.508 & 0.662 \\
Real Income per capita (Rgdpch) & 7,704 & $26,318.53$ & $11,923.58$ & $5,480.58$ & $8,6064.90$ \\
Openness in constant prices (Openk) & 7,704 & 98.91 & 68.71 & 1.77 & 443.18 \\
Consumption share of real GDP (Kc) & 7,704 & 65.09 & 12.40 & 32.43 & 161.24 \\
Investment share of real GDP (Ki) & 7,704 & 23.27 & 6.81 & -33.14 & 47.79 \\
Intermediate import ratio & 7,691 & 0.45 & 0.24 & 0.02 & 1.00 \\
Import content of exports & 7,691 & 0.37 & 0.30 & 0.08 & 6.63 \\
Latin American countries & & & & & 0.63 \\
Growth rate of production per capita & 1,888 & 0.0008 & 0.1724 & -2.0286 & 0.6855 \\
Ln underval & 1,888 & -0.183 & 0.212 & -0.712 & 0.241 \\
Real income per capita (Rgdpch) & 1,888 & $8,295.22$ & $2,147.81$ & $4,668.40$ & $1,2751.51$ \\
Openness in constant prices (Openk) & 1,888 & 42.47 & 15.32 & 18.11 & 82.18 \\
Consumption share of real GDP (Kc) & 1,888 & 71.58 & 4.78 & 60.19 & 77.75 \\
Investment share of real GDP (Ki) & 1,888 & 21.95 & 3.70 & 11.99 & 32.92 \\
Intermediate import ratio & 1,888 & 0.29 & 0.20 & 0.02 & 0.93 \\
Import content of exports & 1,888 & 0.22 & 0.11 & 0.06 & 0.72 \\
\hline
\end{tabular}

Table 3 Baseline model: regression estimates

(1) (2)

\begin{tabular}{lll}
\hline Ln Initial production per capita & $-0.110^{* * * * *}$ \\
Ln underval & $(0.0207)$ & $(0.0208)$ \\
& $0.134 * * *$ & $0.0895^{* * *}$ \\
Ln RGDPCH & $(0.0206)$ & $(0.0274)$ \\
& $0.364 * * *$ & $0.362^{* * *}$ \\
LA $\times$ Ln underval & $(0.0434)$ & $(0.0434)$ \\
& & $0.0804 * *$ \\
Sector-country FE & & $(0.0331)$ \\
Year FE & Yes & Yes \\
Observations & Yes & Yes \\
\hline
\end{tabular}

Robust standard errors in parentheses

$* p<0.10, * * p<0.05$, *** $p<0.01$ 
Table 4 Baseline model plus country controls: regression estimates

(1)

Ln initial production per capita

Ln underval

LA $\times$ underval

Ln RGDPCH

Ln Openk (openness in constant prices)

Ln Kc (consumption share of real GDP)

Ln Ki (Investment share of real GDP)

Sector-country FE

Year FE

Observations

$$
\begin{aligned}
& -0.110 * * *(0.0208) \\
& 0.0840 * * *(0.0280) \\
& 0.0869 * *(0.0338) \\
& 0.358 * * *(0.0437)
\end{aligned}
$$

\begin{tabular}{|c|c|c|c|c|c|c|}
\hline & (1) & (2) & (3) & (4) & (5) & (6) \\
\hline Ln initial production & $-0.114 * * *$ & $-0.115^{* * *}$ & $-0.115^{* * *}$ & $-0.115 * * *$ & $-0.115^{* * *}$ & $-0.115^{* * *}$ \\
\hline per capita & $(0.0225)$ & $(0.0226)$ & $(0.0229)$ & $(0.0225)$ & $(0.0225)$ & $(0.0226)$ \\
\hline \multirow[t]{2}{*}{ Ln underval } & $0.0792 * *$ & $0.199 * * *$ & $0.179 * *$ & $0.0979 * * *$ & $0.172^{* * * *}$ & $0.193 * * *$ \\
\hline & $(0.0326)$ & $(0.0303)$ & $(0.0740)$ & $(0.0261)$ & $(0.0320)$ & $(0.0302)$ \\
\hline \multirow[t]{2}{*}{ LA $\times$ underval } & $0.0962 * * *$ & & & & & \\
\hline & $(0.0364)$ & & & & & \\
\hline Ln underval $\mathrm{X}$ & & $-0.00417 * * *$ & & & & \\
\hline $\mathrm{RGDPCH}_{t-1}$ & & $(0.00144)$ & & & & \\
\hline Ln underval $\mathrm{X}$ & & & -0.0619 & & & \\
\hline$k c_{t-1}$ & & & $(0.118)$ & & & \\
\hline Ln underval $\mathrm{X}$ & & & & $0.0818^{* * *}$ & & \\
\hline openk $_{t-1}$ & & & & $(0.0281)$ & & \\
\hline Ln underval $\mathrm{X}$ & & & & & -0.112 & \\
\hline Interm. imp. ratio & & & & & $(0.0899)$ & \\
\hline Ln underval X & & & & & & $-0.214^{* *}$ \\
\hline Imp. content of Exp & & & & & & $(0.101)$ \\
\hline Country controls & Yes & Yes & Yes & Yes & Yes & Yes \\
\hline Sector-Country FE & Yes & Yes & Yes & Yes & Yes & Yes \\
\hline Year FE & Yes & Yes & Yes & Yes & Yes & Yes \\
\hline Observations & 9,552 & 9,552 & 9,552 & 9,552 & 9,539 & 9,539 \\
\hline
\end{tabular}

Robust standard errors in parentheses

$* p<0.10, * * p<0.05, * * * p<0.01$

Table 5 Baseline model under different interactions terms

Robust standard errors in parentheses

$* p<0.10$, ** $p<0.05$, *** $p<0.01$ 
Table 6 Baseline model and sector heterogenous effect

\begin{tabular}{|c|c|c|c|c|c|}
\hline & \multirow[t]{3}{*}{ (1) } & \multirow{2}{*}{\multicolumn{2}{|c|}{$\frac{\text { Intermediate }}{\text { Imp. ratio }}$}} & \multirow{2}{*}{\multicolumn{2}{|c|}{$\begin{array}{l}\text { Import } \\
\text { Cont. of } \\
\text { exp. }\end{array}$}} \\
\hline & & & & & \\
\hline & & LA & IND & LA & IND \\
\hline Ln initial production per capita & $\begin{array}{c}-0.114 * * * \\
(0.0219)\end{array}$ & & & & \\
\hline Ln underval & $0.0784 * *(0.0308)$ & & & & \\
\hline LA $\times$ underval & $0.0723 * * *(0.022)$ & & & & \\
\hline \multicolumn{6}{|l|}{ Interactions of $\mathrm{LA} \times$ underval with: } \\
\hline 16 Tobacco products & $-0.139 * * *$ & 0.09 & 0.23 & 0.13 & 0.25 \\
\hline 17 Textiles & $0.0526 * * *$ & 0.32 & 0.54 & 0.24 & 0.36 \\
\hline 18 Wearing apparel, fur & 0.0159 & 0.32 & 0.54 & 0.24 & 0.36 \\
\hline 19 Leather, leather products and footwear & $0.0720 * * *$ & 0.32 & 0.54 & 0.24 & 0.35 \\
\hline 20 Wood products (excl. furniture) & $0.0497 * * *$ & 0.11 & 0.28 & 0.11 & 0.29 \\
\hline 21 Paper and paper products & $0.0713 * * *$ & 0.18 & 0.28 & 0.20 & 0.29 \\
\hline 22 Printing and publishing & $0.0154 * *$ & 0.18 & 0.27 & 0.20 & 0.29 \\
\hline 23 Coke, refined petroleum products, nuclear fuel & $-0.0547 * * *$ & 0.16 & 0.35 & 0.28 & 0.60 \\
\hline 24 Chemicals and chemical products & $0.00586^{* * *}$ & 0.38 & 0.62 & 0.23 & 0.38 \\
\hline 25 Rubber and plastics products & $-0.0302 * * *$ & 0.31 & 0.45 & 0.29 & 0.38 \\
\hline 26 Nonmetallic mineral products & $0.0927 * * *$ & 0.11 & 0.25 & 0.13 & 0.26 \\
\hline 27 Basic metals & $0.0822 * * *$ & 0.27 & 0.52 & 0.21 & 0.41 \\
\hline 28 Fabricated metal products & $0.0806 * * *$ & 0.26 & 0.29 & 0.23 & 0.33 \\
\hline 29 Machinery and equipment n.e.c. & $0.125 * * *$ & 0.50 & 0.57 & 0.26 & 0.35 \\
\hline 30 Office, accounting and computing machinery & $-0.343 * * *$ & 0.80 & 0.77 & 0.49 & 0.48 \\
\hline 31 Electrical machinery and apparatus & $-0.0255^{* *}$ & 0.60 & 0.59 & 0.29 & 0.41 \\
\hline 32 Radio, television and communication equipment & $-0.143^{* * *}$ & 0.69 & 0.70 & 0.33 & 0.65 \\
\hline 33 Medical, precision and optical instruments & $0.0904 * * *$ & 0.27 & 0.65 & 0.15 & 0.38 \\
\hline 34 Motor vehicles, trailers, semitrailers & $0.184 * * *$ & 0.46 & 0.64 & 0.33 & 0.45 \\
\hline 35 Other transport equipment & $0.242 * * *$ & 0.29 & 0.51 & 0.19 & 0.36 \\
\hline 36 Furniture; manufacturing n.e.c. & -0.00448 & 0.23 & 0.30 & 0.21 & 0.31 \\
\hline Country controls & Yes & & & & \\
\hline Sector-country FE & Yes & & & & \\
\hline Year FE & Yes & & & & \\
\hline Observations & 9,552 & & & & \\
\hline
\end{tabular}

Error term clustered by sector

$* p<0.10, * * p<0.05, * * * p<0.01$

\section{References}

Aten R, Heston A, Summers R (2011) Penn World Table version 7.0. Center for International Comparisons of Production, Income and Prices at the University of Pennsylvania

Baer W, Kerstenetzky I (1964) Import substitution and industrialization in Brazil. Am Econ Rev 54(3):411-425 
Baer W (1972) Import substitution and industrialization in Latin America: experiences and interpretations. Latin Am Res Rev 7(1):95-122

Baer W (1984) Industrialization In Latin America: successes and failures. J Econ Edu 15(2):124-135

Baer W (2014) The Brazilian economy: growth and development, 7th edn. Lynne Rienner Publisher, Boulder

Balassa B (1964) The purchasing power parity doctrine: a reappraisal. J Polit Econ 72(6):584-596

Berg A, Miao Y (2010) The real exchange rate and growth revisited: the Washington consensus strikes back? IMF Working Papers 10/58, International Monetary Fund

Eichengreen B (2008) The real exchange rate and economic growth. Commission on growth and development, Working Paper No.4. http://www.growthcommission.org/storage/cgdev/documents/ gc-wp-004_web.pdf

Gala P (2008) Real exchange rate levels and economic development: theoretical analysis and econometric evidence. Camb J Econ 32(2):273-288

Imbs J (2007) Growth and volatility. J Monet Econ 54(7):1848-1862

Imbs J, Wacziarg R (2003) Stages of diversification. Am Econ Rev 93(1):63-86

Kiyotaki N, Moore J (1997) Credit cycles. J Polit Econ 105(2):211-48

Little I, Scitovsky T, Scott M (1970) Industry and trade in some developing countries. Oxford University Press for the OECD

Rajan RG, Zingales L (1998) Financial dependence and growth. Am Econ Rev 88(3):559-86

Rajan RG, Subramanian A (2011) Aid, Dutch disease, and manufacturing growth. J Dev Econ 94(1):106-118

Rodrik D (2008) The real exchange rate and economic growth. Brookings Papers on Economic Activity, Fall

Samuelson PA (1964) Theoretical notes on trade problems. Rev Econ Stat 46(2):145-154

Shafaeddin SM (2005) Trade liberalization and economic reform in developing countries: structural change or de-industrialization? UNCTAD Discussion Papers 179, United Nations Conference on Trade and Development 